\title{
Management of hemangiomas by propranolol: Epidemiological, clinical and therapeutic aspects: Retrospective study about 15 cases
}

\section{Moussa Doulla', Harouna Bako², Laouali Salissou', Maimouna M Ouédraogo', Ide Hassane ${ }^{3}$, Mariama Abdoulaye', Hassan Moumouni ${ }^{4}$}

${ }^{1}$ Department of Dermatology Venerology, National Hospital of Niamey, Niger, ${ }^{2}$ National Center Dermato-Leprosy, Niamey, Niger, ${ }^{3}$ Cardiology Department, National Hospital of Niamey, Niger, ${ }^{4}$ Laboratory of Cytology and Genetics, Faculty of Health Sciences, Niamey, Niger

Corresponding author: Dr. Laouali Salissou, E-mail: danmata@yahoo.com

\begin{abstract}
The objective of this study was to determine the epidemiological, clinical and therapeutic profile of cutaneous hemangioma at the Niamey National Hospital. This is a retrospective study carried out over a period of 2 years, in the Unity of Dermatology and Venerology. Out of a total of 1648 consultations in 2 years, 33 cases of cutaneous angioma were identified; which represented $2 \%$. The prevalence was predominantly female $(80 \%)$ and the sex ratio $\mathrm{M} / \mathrm{F}$ was 0.25. The age group $0-5$ months was more represented (66.7\%) with ages ranging 2 days and 24 months. Of the 33 cases of angioma, 25 were hemangiomas and 8 were malformations without any cardiac anomalie. Patients retained for the study were those with hemangioma (25 cases with 76\%) who received the Propranolol protocol used in the oral dosage of $1 \mathrm{mg} / \mathrm{kg} /$ day for 24 months. Only 15 patients recovered totally from hemangioma. Tolerance was good in 93.3\%. Conclusion: Several therapies still show their limit. Due to the often serious side effects with corticosteroids, treatment based on betablockers can be a way of the future, given the satisfaction of results and the good tolerance to these molecules.
\end{abstract}

Key words: Angioma; Hemangioma; Propranolol

\section{INTRODUCTION}

Angiomas are a heterogeneous group of vascular diseases including hemangiomas and malformations [1-3]. Immature angioma or hemangioma is a benign vascular tumor of undetermined etiology following proliferation of endothelial and mesenchymal cells with formation of neo-vessels in the dermis [4,5]. They are the most common tumors of the child, with a prevalence of $10 \%$ and whose diagnosis is essentially clinical [4-6]. The management uses various methods namely: corticosteroid therapy, surgery, laser, radiotherapy, interferon, betablockers that currently seem the most used $[5,7,8]$. The purpose of this study was to determine the epidemiological and clinical aspects of angiomas, but also to evaluate the outcome of the management of hemangioma by a betablocker, that is Propranolol.

\section{MATERIAL AND METHODS}

This is a retrospective study lasting 2 years from January 1, 2012 to December 31, 2013, conducted at the Dermatology and Venereology Department of the National Hospital of Niamey. The information was collected from the consultation records using a survey card containing epidemiological, clinical, paraclinical and therapeutic data. Included in this study were all

\footnotetext{
How to cite this article: Doulla M, Bako H, Salissou L, Ouédraogo MM, Hassane I, Abdoulaye M, Moumouni H. Management of hemangiomas by propranolol: Epidemiological, clinical and therapeutic aspects: retrospective study about 15 cases. Our Dermatol Online. 2018;9(1):7-10.

Submission: 05.05.2017; Acceptance: 21.11.2017

DOI: 10.7241/ourd.20181.2
} 
cases of skin hemangiomas diagnosed and treated with Propranolol tablet for 24 months. The protocol of Propranolol was as follows: $1 \mathrm{mg} / \mathrm{kg} /$ day diluted in tap water, and administered with a $10 \mathrm{ml}$ syringe. The intake was $5 \mathrm{ml}$ in the morning and $5 \mathrm{ml}$ in the evening. Patients with vascular malformation and cases of hemangioma lost from the study were excluded from the study. The data was entered on the Epi-info software version 3.5.1 and transferred to the EXCEL software for analysis.

\section{RESULTS}

During the study period, we collected 33 cases of cutaneous angioma out of 1648 consultations, either a frequency of $2 \%$. Of these 33 cases, 25 patients $(76 \%$ ) had hemangioma and 8 had vascular malformation (24\%). Fifteen out of twenty five patients with hemangioma (26\%) performed Propranolol treatment, including 12 girls and 3 boys. The concept of consanguinity was found in $6.7 \%$ of cases. Patients younger than 5 months were the most represented $(66.7 \%)$. The average age
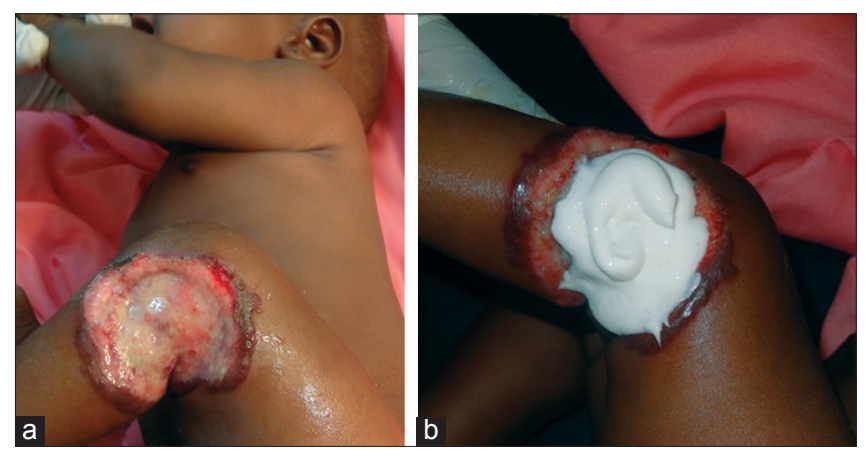

Figure 1: (a) Ulcerated hemangioma of the outer face of the left knee. (b) Ulcerated hemangioma of the outer face of the left knee.

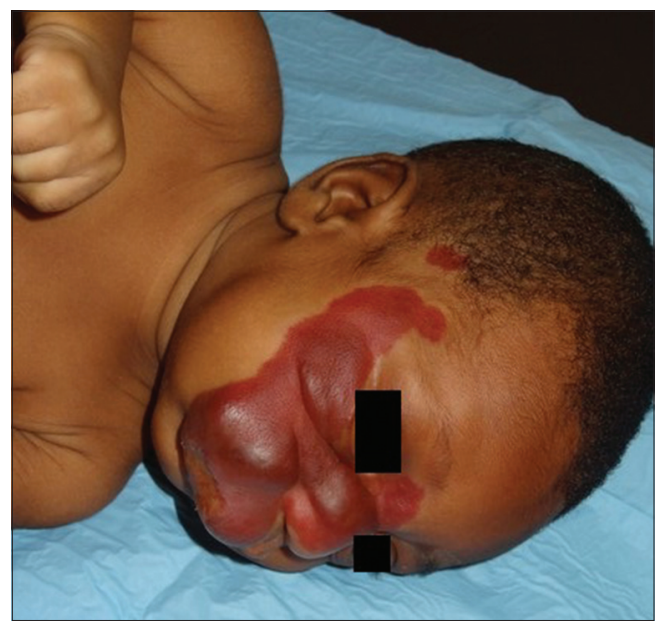

Figure 2: Hemangioma disfiguring the right hemiface. was 5.8 months and the extremes were 2 days and 24 months. Hemangiomas appeared 2 months after birth in $46.6 \%$ of cases, with a predominant localization in the cephalic region (forehead and cheeks) (Table I).

The pre-therapeutic assessment carried out namely: Glycemia, Transaminases, Creatinemia, ECG, was without any particularity. Tolerance to oral therapy was good in all patients. Local treatment has been associated with trolamine in ulcerated hemangiomas (Figs 1A and 1B) Complications were noted in 6 cases (40\%): either aesthetic type (Fig. 2) in $83 \%$ of cases, or infectious type in $16.7 \%$ of cases (Fig. 3). Treatment evolution was favorable in $93.3 \%$ of cases (Figs. 1A and 4).

\section{DISCUSSION}

Out of a total of 1648 consultations in 2 years, 33 cases of cutaneous angioma were collected, either a frequency of $2 \%$. Lower frequencies have been reported: In Mali, GUINDO O et al. reported on 4544 dermatological consultations 31 cases of angiomas during a study period from 19 July 2005 to 23 April 2009, ie 0.68\% [9]; in Burkina Faso TRAORE FB et al. in 2003 found 12 cases of angiomas among 14265 patients consulted during the study period from January 1, 1992 to December 31, 1996, a frequency of $0.08 \%$ [10].In our study the sex ratio was 1 man for 4 women. Most studies have reported a female predominance $[7,11,12-14]$. In literature this predominance of women has no explanation yet [15].

The 0-5 month age group was the most represented in our study $(66.7 \%)$, with an average age of 5.8 months. This average age was lower than that reported by some authors with respectively 9.65 months and 13.06 months $[11,13]$. As in our case with $6.7 \%$, the notion of consanguinity is poorly reported in the literature $[11,16,17]$. We reported the presence of hemangiomas in $46.6 \%$ at birth; This corroborates data from the literature which shows that lesions may be present at birth or may appear in the days or weeks following birth $[17,18]$. We have noted a ubiquitous

\begin{tabular}{lcc} 
Table I: Distribution of patients by topography & \\
\hline Topography & Patients & Percentage (\%) \\
\hline Forehead & 6 & 40 \\
Cheeks & 5 & 33,33 \\
Knees & 1 & 6,66 \\
Legs & 3 & 20 \\
Total & 15 & 100,0 \\
\hline
\end{tabular}




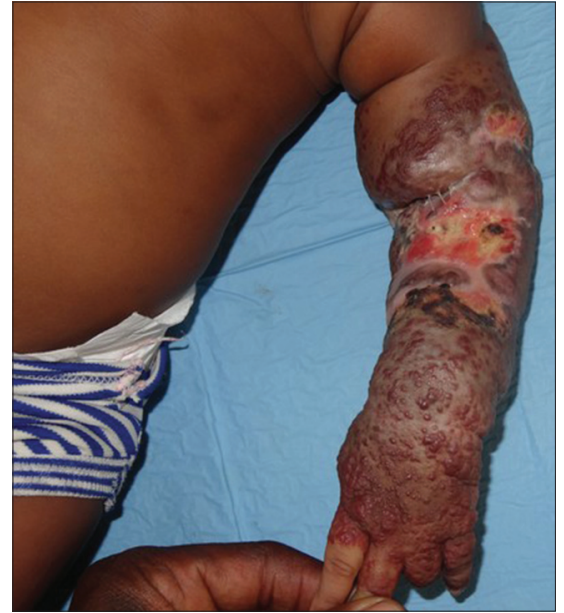

Figure 3: Impetigentiated hemangioma of the left thoracic limb.

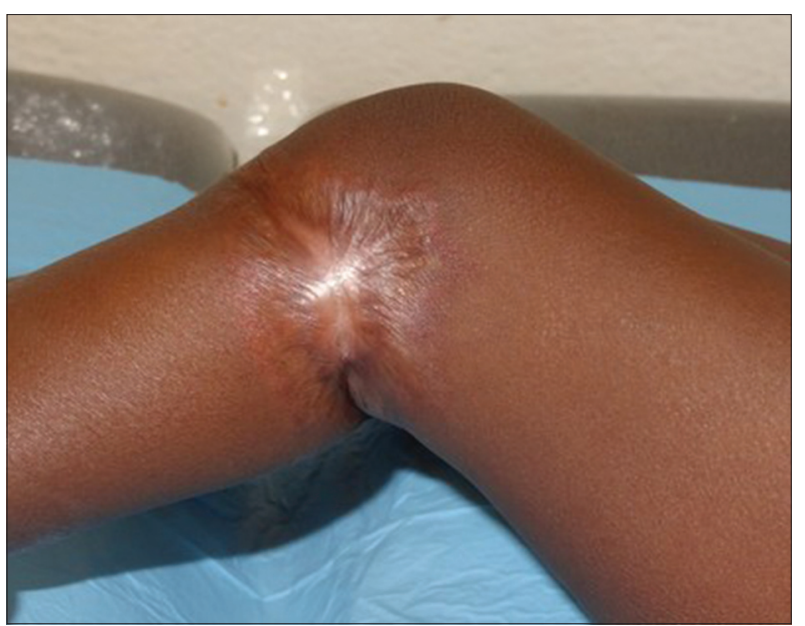

Figure 4: Ulcerated hemangioma after treatment with retractile scar.

distribution of lesions, as reported by some authors with, however, as in our series a cephalic predominance $[12,18,19]$. From the therapeutic point of view, since the observation of their effectiveness, betablockers are the subject of several studies [20-23]. In our study we noted a remarkable efficacy of Propranolol in 93.3\% after 24 months of treatment. Despite the low dose we used $(\mathrm{lm} / \mathrm{kg} / \mathrm{d})$, our results are similar to those of some series with $84 \%$ efficacy [17], at a dose of 3 $\mathrm{mg} / \mathrm{kg} /$ day on also a period of 24 months; and even higher than those of a study reporting $46 \%$ efficacy using a dose of $2 \mathrm{mg} / \mathrm{kg} /$ day [24]. Tolerance was good in all cases, but some authors have reported side effects such as hypoglycaemia, diarrhea, vomiting, insomnia, low blood pressure, cold extremities [12,25]. Our percentages of healing (93.3\%) are comparable to those of some literatures who obtained $88.2 \%$ [21]. In our study we noted complications in $40 \%$ of cases, type of infection and aesthetic damage. The aesthetic damage was observed in $83.3 \%$, and was significantly higher than that reported by Yacouba K. with 63.6\% [26]. There is no standard rating of these harms, however, it is reported in the literature that severe forms account for less than $5 \%[17,18]$.

\section{CONCLUSION}

In this study cutaneous angioma represents $2 \%$ of dermatological consultations. The predominance of female cases may be related to aesthetic reasons. The efficacy and tolerability of Propranolol treatment was significant and favorable. A prospective study on a more significant number of cases, will confirm the choice of betablockers in the management of hemangiomas.

\section{Statement of Human and Animal Rights}

All procedures followed were in accordance with the ethical standards of the responsible committee on human experimentation (institutional and national) and with the Helsinki Declaration of 1975, as revised in 2008 .

\section{Statement of Informed Consent}

Informed consent was obtained from all parent patients for being included in the study.

\section{RÉFÉRENCES}

1. Odile Enjolras, Véronique Soupre, Arnaud Picard. Classification des anomalies vasculaires Superficielles. Presse Med. 2010;39:457-64.

2. A. Dompmartin. Classification des anomalies vasculaires. Ann Dermatol Vénérol. 2013;140:337-9.

3. Tiemtoré-Kambou BMA, Ouédraogo NA, Ndé/Ouédraogo NA, Traoré F, Ouédraogo PA, Dao BA, Ouattara B, et al. Angioma plane of the face: About two cases of which one revealing sturge weber and krabbe syndrome. Our Dermatol Online. 2017;8:70-4.

4. Bonnetblanc J-M: Angiomes Cutanés. Ann Dermatol Vénérol. 2012;139: A185-A91.

5. Eschard C. Hémangiomes infantiles. Quand explorer et actualités thérapeutiques. Ann Dermatol Vénérol. 2015;142:476-82.

6. Chiller KG, Passaro D, Fieden IJ. Hemangiomas of infancy clinical characteristics, morphologic subtypes and their relationship to race, ethnicity and sex. Arch Dermatol. 2002;138:1567-76.

7. David LR, Malek MM, Argenta LC. Efficacity of pulsed dye laser therapy for the treatment of ulcerated hemangiomas: a review of 78 patients. Br J Plast Surg. 2003;56:317-27.

8. Achauer BM, Chang CJ, Vander Kam VM. Management of hemangioma of infancy: review of 245 patients. Plast Reconstr Surg. 1997;99:1301-8.

9. GUINDO O. Aspects épidémiologiques, cliniques et thérapeutiques des angiomes immatures. ['institut Marchoux]: Bamako; 2000.

10. Ttaroe FB, Traroe A, Konate I, Traroe S. Tumeurs cutanéo- muqueuses: aspects épidémiologiques. Cah études recherc francoph/Santé Avril 200313 (2).

11. Fatemeh L, Pouran L, Behzad A, Mohammad A T, Maryam A M, Ali T. Propranolol for infantile hemangioma: An evaluation of its 
efficacy and safety in Iranian infants. Iranian Jr Neonat. 2016:7:20.

12. Marlies G, Johannes M. Adverse effects of propranolol when used in the treatment of hemangiomas: A case series of 28 infants. J Am Acad Dermatol. 2011;65:320-7.

13. R. Gammoudi L, Boussofara W, Saidi A, Aounallah N, Ghariani C, Belajouza P, et al. Le propranolol dans l'hémangiome infantile. Ann Dermatol Vénérol. 2014;141:336-7.

14. Bouras M, Khadir K, Fatwaki FZ, Hali F, Salimi S, Chbani K, et al. Évaluation à long terme de l'efficacité du propranolol par voie orale dans le traitement des hémangiomes infantiles: étude prospective de 68 cas. Ann Dermatol Vénérol. 2013;140:1-4.

15. Enjolras O. Quoi de neuf dans les angiomes ? Tumeurs vasculaires infantiles. Nouv Dermatol. 2003;22:602-4.

16. Ousi B. Traitement des angiomes plans de l'adulte par laser KTP. Journ Paris Grp Laser Soc Fr Dermatol. 2007;26:34-8.

17. Enjolras O. Anomalies vasculaires superficielles : les «angiomes. Encycl Méd Chir. (Editions Scientifiques et Médicales Elsevier SAS, Paris), Paris; 2001. p. 15.

18. Lemarchand, Venencie F, Enjolras O. Angiomes et malformations vasculaires. Dermatologie et infections sexuellement transmissibles. 4 ème édition. Paris; 2004;696-703.

19. Lemarchand F-V, Enjolras O, Bisdorff A-B. Dermatologie et infections sexuellement transmissibles: Angiomes et malformations vasculaires [Internet]. Elsevier Masson; 2008. Available from: www. em-consulte.com/article/195571/réference

20. Léauté-Labrèze C. Traitement par propranolol des hémangiomes infantiles. Arch Pédiat. 2015;22:452-5.

21. Price CJ. Propranolol vs Corticosteroids for Infantile Hemangiomas:
A Multicenter Retrospective Analysis. Arch Dermatol. 2001;147:1371.

22. Holmes WJ, Mishra A, Gorst C, Liew SH. Propranolol as first-line treatment for rapidly proliferating infantile haemangiomas. J Plast Reconstr Aesthet Surg. 2011;64:445-51.

23. Chik KK, Luk CK, Chan HB, Tan HY. Use of propranolol in infantile haemangioma among Chinese children. Hong Kong Med J. 2010;16:341-6.

24. Léaute-Labrèze C, Prey S, Ezzedine K. Infantile haemangioma: Part I. Pathophysiology, epidemiology, clinical features, life cycle and associated structural abnormalities and Part.II : Risks, complications and treatment. J Eur Acad Dermatol Venerol. 2011;25:1245-53.

25. Holland KE, Frieden IJ, Frommelt PC, Mancini AJ, Wyatt D, Drolet BA, Hypoglycemia in Children Taking Propranolol for the Treatment of Infantile Hemangioma. Arch Dermatol. 2010;146:775-8.

26. Diarra YK, Rhaly AA, Cisse IA, Traroe B, Diawara KH. Aspects épidémiologiques et cliniques des angiomes au CHU de Gabriel Toure. [CHU de Gabriel Toure Bamako]: faculté de Médecine, de Pharmacie et d'Odonto- Stomatologie; 2010.

Copyright by Moussa Doulla, et al. This is an open-access article distributed under the terms of the Creative Commons Attribution License, which permits unrestricted use, distribution, and reproduction in any medium, provided the original author and source are credited.

Source of Support: Nil, Conflict of Interest: None declared. 